\title{
HEAVY METAL TOLERANCE AND REMOVAL EFFICIENCY OF THE Rhodotorula mucilaginosa AND Saccharomyces boulardii PLANKTONIC CELLS AND BIOFILM
}

\author{
Sandra M. Grujić, Ivana D. Radojević*, Sava M. Vasić, \\ Ljiljana R. Čomić, Aleksandar M. Ostojić \\ University of Kragujevac, Faculty of Science, Department of Biology and Ecology, \\ Radoja Domanovića 12, 34000 Kragujevac, Republic of Serbia \\ *Corresponding author; E-mail: ivana@kg.ac.rs
}

(Received March 11, 2018; Accepted May 12, 2018)

\begin{abstract}
The impact of heavy metals, cadmium $\left(\mathrm{Cd}^{2+}\right)$, zinc $\left(\mathrm{Zn}^{2+}\right)$ and nickel $\left(\mathrm{Ni}^{2+}\right)$ on planktonic cells and biofilm of Rhodotorula mucilaginosa and Saccharomyces boulardii was examined. The metal tolerance testing was performed by $\mathrm{MBEC}^{\mathrm{TM}}-\mathrm{HTP}$ assay. The minimum inhibitory concentration (MICp) and minimum lethal concentration (MLCp) were determined as well as the minimum biofilm eradication concentration (MBEC). Biofilm was more tolerant on the presence of heavy metals than the planktonic cells. The planktonic cells of $R$. mucilaginosa were tolerant to high concentrations of $\mathrm{Cd}^{2+}, \mathrm{Zn}^{2+}$ and $\mathrm{Ni}^{2+}$, while the planktonic cells of $S$. boulardii tolerated $\mathrm{Zn}^{2+}$, exclusively. The $R$. mucilaginosa biofilm was tolerant to all of the tested metal concentrations and the obtained results were confirmed by fluorescence microscopy. S. boulardii did not show ability of biofilm formation. Metal removal efficiency of the $R$. mucilaginosa planktonic cells and biofilm were also tested. The $R$. mucilaginosa biofilm showed higher efficiency in metals removing compared to the planktonic cells. Until now, the heavy metal tolerance and the removal efficiency $\left(\mathrm{Cd}^{2+}, \mathrm{Zn}^{2+}\right.$ and $\left.\mathrm{Ni}^{2+}\right)$ analyzes were performed solely on planktonic cells of Rhodotorula species. In this study, we investigated the metal removal efficiency of $R$. mucilaginosa planktonic cells and biofilm and compared the obtained results.
\end{abstract}

Keywords: biofilm, metals, tolerance, removal, Rhodotorula mucilaginosa, Saccharomyces boulardii.

\section{INTRODUCTION}

An understanding of the nature of heavy metals, their relationships and toxicity or deficiency problems associated with them, is important for environmental protection. As more and more analytical data become available in the world literature, it is evident that considerable areas in many parts of the world have been contaminated with heavy metals, which present potential toxicity problems (ALLOWAY, 1995). 
A wide range of methods for the heavy metals removal from contaminated environment are being used. Most of them are not efficient in removing low concentrations of metals, have high energy requests, lead to accumulation of toxic sludge and other waste products, therefore requiring a careful disposal of waste (AHALYA et al., 2003). With increasing ecological awareness, search for effective alternative technologies is essential. Microbial biomass is considered as an alternative for the heavy metals removal (ALLURI et al., 2007).

Some authors reported nickel tolerance of planktonic cells Rhodotorula mucilaginosa (SAN and DÖNMEZ, 2012) and Rhodotorula glutinis (SUAZO-MADRID et al., 2011). Cadmium tolerance was tested by planktonic cells of Rhodotorula Y11 (LI and YUAN 2006, 2008) and Rhodotorula rubra (SALINAS et al., 2000). The heavy metal tolerance of biofilms are taking a great attention, since they could be applied in bioremediation of polluted environments. HARRISON et al., (2006) reported that Candida tropicalis could survive in the most adverse environmental conditions, thanks to the ability to form a biofilm.

Heavy metal tolerance is associated with the ability to remove heavy metals from the environment (FAZLI et al., 2015). Recently, it was reported that $R$. rubra (planktonic cells) have a potential application in degradation and bioleaching of heavy metals (REZZA et al., 2001). The accumulation of lead and cadmium by $R$. rubra biomass was tested (SALINAS et al., 2000), as well as the removal of nickel by planktonic cells of Rhodotorula sp. (LI and YUAN, 2008).

In previous studies, the heavy metal tolerance and the removal potential for $\mathrm{Cd}^{2+}, \mathrm{Zn}^{2+}$ and $\mathrm{Ni}^{2+}$ have been focused on planktonic cells of Rhodotorula species, exclusively (SALINAS et al., 2000, REZZA et al., 2001, LI and YUAN, 2008, SUAZO-MADRID et al., 2011, SAN and DöNMEZ, 2012). Only one study has reported heavy metal removal efficiency for $\mathrm{Zn}^{2+}$ by Candida rugosa and Cryptococcus laurentii biofilms (BASAK et al. 2014). In our previous investigations, we concluded that $R$. mucilaginosa biofilm was few times more tolerant and had a higher potential for removing $\mathrm{Hg}^{2+}, \mathrm{Cu}^{2+}$ and $\mathrm{Pb}^{2+}$ ions than planktonic cells (GRUJIC et al. 2017a). Furthermore, the $R$. mucilaginosa/Escherichia coli mixed biofilm was more efficient in removing heavy metals than their mono-species biofilms (BUZEJIĆ et al., 2016, GRUJIC et al., 2017b). These findings led to the further development of studies on the $\mathrm{Cd}^{2+}$, $\mathrm{Zn}^{2+}$ and $\mathrm{Ni}^{2+}$ ion tolerance and removal efficiency of planktonic cells and biofilm of $R$. mucilaginosa and Saccharomyces boulardii, including comparative analysis with the previously obtained results.

\section{MATERIALS AND METHODS}

\section{Microorganisms and growth conditions}

Two species of yeast were used $-R$. mucilaginosa (isolated from the environment) and $S$. boulardii (commercial probiotic). The $R$. mucilaginosa was identified by the test for rapid identification of yeast API $20 \mathrm{C}$ AUX (Biomerieux, France). Tryptic soy broth (TSB) was chosen as the growth medium for all metal tolerance assays (HARRISON et al., 2006). For the metal removal assays, YPED medium was used (MUNEER et al., 2007). All serial dilutions were carried out using $0.9 \%$ saline.

\section{Cultivation of biofilms}

Growth of the selected yeasts in the presence of heavy metals was tested by quantitative assay in the MBEC-HTP device (MBEC BioProducts, Innovotech, Canada) as previously described (CERI et al., 1999). Plastic lid with 96 pegs that fits inside a standard 96- 
well microplate was used. The peg lid was immersed into a sterile solution of $1 \%$ L-lysine in distilled water $\left(\mathrm{dH}_{2} \mathrm{O}\right)$ and incubated at room temperature for $16 \mathrm{~h}$.

Cryogenic stocks cultures of $R$. mucilaginosa and $S$. boulardii were streaked out twice on TSA and incubated at $26^{\circ} \mathrm{C}$ for $48 \mathrm{~h}$. The growth was monitored throughout $48 \mathrm{~h}$. This culture was used for inoculum preparation for setting MBEC-HTP device. Inoculum was prepared in TSB to match a $1.0 \mathrm{McF}$ arland standard and diluted 30 -fold in TSB. $150 \mu \mathrm{L}$ of inoculum was transferred into each well of a 96-well microtiter plate. The dried, L-lysinecoated peg lids were then inserted into 96-well microtiter plate containing this inoculum, and placed for $48 \mathrm{~h}$ in incubator at $26^{\circ} \mathrm{C}$.

\section{Preparation of metal solution}

Tolerance of the planktonic cells and biofilms was tested in the presence of $\mathrm{Cd}^{2+}$, $\mathrm{Zn}^{2+}$, and $\mathrm{Ni}^{2+}$ metal ions originating from the $\mathrm{CdSO}_{4}, \mathrm{ZnSO}_{4}, \mathrm{NiSO}_{4}$ salts (Sigma). All metal compounds were dissolved in the sterile distilled water. Stock solutions were filtered using the $0.2 \mu \mathrm{m}$ syringe filter. Work solutions of metals were diluted in TSB from stock solutions, to prepare challenge media, no more than 60 minutes before the exposure. Used concentrations were in accordance with the concentrations used in the study of AL-ENZI and AL-CHARRAKH (2013). Range of concentrations for nickel was from 1.30 to $20.67 \mathrm{mM}$; for cadmium and zinc was $0.1,1,10$ and $100 \mathrm{mM}$. Range of concentrations for amphotericin B was: $0.24 ; 0.47 ; 0.94 ; 1.89 ; 3.78 ; 7.57 ;$ and $15.15 \mu \mathrm{g} / \mathrm{mL}$. This antimycotic was a control for yeast cells susceptibility, not to compare with metals. The $\mathrm{Zn}^{2+}$ and $\mathrm{Cd}^{2+}$ ions were neutralized using $10 \mathrm{mM}$ reduced glutathione while the $\mathrm{Ni}^{2+}$ ions were chelated with $0.5 \mathrm{mM}$ reduced glutathione (HARRISON et al., 2006). Based on the previous studies on metal removal potential, selected concentration was $100 \mu \mathrm{g} / \mathrm{mL}$ for each metal (BASAK et al., 2014).

\section{Tolerance of planktonic cells to heavy metals}

The tolerance of the R. mucilaginosa and S. boulardii planktonic cells was determined according to the method described by CERI et al. (1999). The culture inoculum was prepared in McFarland 1.0 and diluted 30-fold in TSB for setting MBEC-HTP device. Each well of a 96-well microtitre plate was set with $150 \mu \mathrm{L}$ with plastic lid with 96 pegs. After 48-h incubation at $26{ }^{\circ} \mathrm{C}$, biofilm was formed on peg and planktonic cells left in wells were both used for metal challenge.

\section{Tolerance of biofilms to heavy metals}

Tolerance of biofilms was evaluated as previously described by HARRISON et al. (2006). The peg lid (with the formed biofilms) was immersed in the 96-well microtiter plates containing TSB with metal salt in the appropriate concentrations. The challenge plates were incubated at $26^{\circ} \mathrm{C}$ for $48 \mathrm{~h}$.

After exposure period, pegs with biofilm were removed from the challenge plates and washed twice with sterile $0.9 \%$ saline. Plastic lid with pegs, was transferred to a new plate with TSB containing neutralizer $(200 \mu \mathrm{L}$ per well). After neutralization, plastic lid with pegs was transferred to a plate with TSB and the entire plate was exposed to the ultrasonic waves, the frequency of $20 \mathrm{kHz}$ to $400 \mathrm{kHz}$ for $5 \mathrm{~min}$ in a water bath for sonification (Aquasonic 250 HT Ultrasonic Cleaner, VWR International, Radnor, PA, USA). This microtiter plate was marked as recovery plate and it was incubated for $48 \mathrm{~h}$ at $26^{\circ} \mathrm{C}$. After the incubation period, minimum biofilm eradication concentration (MBEC) was obtained using ELISA microplate reader $\left(\mathrm{OD}_{650}\right)$ (Rayto, China). 


\section{Fluorescence microscopy}

Fluorescence microscopy was used to evaluate the effect of metals on the $R$. mucilaginosa biofilm according to the method described by KRONVALL and MYHRE (1977) with some modifications. The content of the recovery microtiter plate was removed. $50 \mu \mathrm{L}$ of methanol was added in each well of microtiter plate. Microtiter plate was incubated at room temperature until methanole vaporized. $50 \mu \mathrm{L}$ of acridine orange $(5 \mathrm{mg} / \mathrm{mL})$ was added in each well. After $2 \mathrm{~min}$, the microtiter plate was washed with sterile distilled water. The $R$. mucilaginosa biofilm was observed on the Olympus BX51 fluorescence microscope (Olympus, Shinjuku, Tokyo, Japan) and analyzed using Cytovision 3.1 software package (Applied Imaging Corporation, Santa Clara, California, USA).

\section{Metal removal efficiency using planktonic cell}

Metal removal efficiency was analyzed according to the method described by MUNEER et al. (2007). The cells were grown in $250 \mathrm{ml}$ Erlenmeyer flasks containing $100 \mathrm{ml}$ of YPED medium. One flask was the control and other three contained YPED medium, suspension, and metals with concentration of $100 \mu \mathrm{g} / \mathrm{ml}$. The flasks were incubated at $26{ }^{\circ} \mathrm{C}$. Growth of the $R$. mucilaginosa planktonic cells was determined by reading optical density at $520 \mathrm{~nm}$ (OD520) after 12, 24, and $48 \mathrm{~h}$. At the same time, from the flasks with tested metal, $5 \mathrm{ml}$ of aliquots was taken out and cells were separated by centrifugation. The supernatant (samples and controls) were subjected to spectrophotometer $(357.9 \mathrm{~nm})$ analysis for residual metal concentration. All experiments were performed in triplicates and their mean value was calculated.

The metal removal percentage (\%) was calculated from the following equation (1):

$$
E(\%)=\frac{(C i-C r)}{C i} \times 100
$$

where $\mathrm{C} i$ is the initial concentration of metal ion $(\mu \mathrm{g} / \mathrm{mL})$ and $\mathrm{Cr}$ is the final concentration of metal ion $(\mu \mathrm{g} / \mathrm{mL})$.

\section{Metal removal efficiency using biofilm}

Metal removal efficiency was analyzed according to the method described by BASAK et al. (2014). Biofilm was formed on $22 \times 22 \mathrm{~mm}$ polyvinyl plastic coverslips placed in each well of a 6-well culture plate. Fifty microliters of suspension (McFarland 1.0) was added to each well with $5 \mathrm{ml}$ YPED medium. Coverslips with formed biofilm were placed in the new 6 -well plate that contained tested metals individually, with concentration of $100 \mu \mathrm{g} / \mathrm{ml}$. After 12,24 , and $48 \mathrm{~h}$ incubation period, $1.5 \mathrm{~mL}$ aliquots were taken and centrifuged at $10000 \mathrm{rpm}$ for $5 \mathrm{~min}$. The supernatant (samples and controls) were subjected to spectrophotometer (520 $\mathrm{nm}$ ) analysis for residual metal concentration. All experiments were performed in triplicates and their mean value was calculated.

The metal removal percentage $(\%)$ was calculated from the equation 1. 


\section{RESULTS AND DISCUSSION}

\section{Tolerance of planktonic cells on heavy metals}

Heavy metal tolerance of $R$. mucilaginosa and $S$. boulardii planktonic cells, for the exposure period of $48 \mathrm{~h}$, was analyzed. The planktonic cells of $R$. mucilaginosa showed high tolerance in the presence of metals $\left(\mathrm{Cd}^{2+}, \mathrm{Zn}^{2+}\right.$ and $\left.\mathrm{Ni}^{2+}\right)$, while $S$. boulardii showed tolerance toward $\mathrm{Zn}^{2+}$ only. The results are presented in the Table 1 .

Table 1 . Heavy metal tolerance of $R$. mucilaginosa and $S$. boulardii planktonic cells at exposure period of $48 \mathrm{~h}$.

\begin{tabular}{lccc}
\multicolumn{1}{c}{ Species } & Test substance & 1 MICp & 2 MLCp \\
\hline$R$. mucilaginosa & $\mathrm{Cd}^{2+}$ & 10 & 100 \\
$R$. mucilaginosa & $\mathrm{Zn}^{2+}$ & 10 & 100 \\
$R$. mucilaginosa & $\mathrm{Ni}^{2+}$ & 5.17 & 10.33 \\
R. mucilaginosa & Amphotericin B & 15.15 & $>15.15$ \\
S. boulardii & $\mathrm{Cd}^{2+}$ & $<0.1$ & $<0.1$ \\
S. boulardii & $\mathrm{Zn}^{2+}$ & 0.1 & 1 \\
S. boulardii & $\mathrm{Ni}^{2+}$ & $<1.3$ & $<1.3$ \\
S. boulardii & Amphotericin B & $<0.24$ & $<0.24$ \\
\hline
\end{tabular}

${ }^{1} \mathrm{MICp}$ - Minimum inhibitory concentration of planktonic cells;

${ }^{2}$ MLCp - Minimum lethal concentrations of planktonic cells;

given as $\mathrm{mM}$ for metals and $\mu \mathrm{g} / \mathrm{mL}$ for antimycotic.

Cadmium tolerance of Rhodotorula sp. Y11 was reported by LI and YUAN (2006, 2008), with the highest tolerated concentration of $0.1 \mathrm{mM}$. In our study, $R$. mucilaginosa tolerated cadmium concentration up to $10 \mathrm{mM}$. A possible reason for the disparity may be the species difference, even though they belong to the same genus. The $R$. mucilaginosa species in this study was isolated from environment, which also may influence the obtained results. In another study, $R$. rubra tolerated cadmium to concentration of $10 \mathrm{mM}$ (SALINAS et al., 2000), which is in accordance with our results.

The tolerance of $R$. mucilaginosa to the presence of $50 \mathrm{mg} / \mathrm{L}$ nickel was previously reported by SAN and DÖNMEZ (2012). Furthemore, the tolerance of another species, $R$. glutinis to the presence of nickel under concentration range from 10 to $400 \mathrm{mg} / \mathrm{L}$ was reported by SUAZO-MADRID et al. (2011). In our study, the range of concentrations was significantly higher, ranging from 100 to $3200 \mathrm{mg} / \mathrm{L}$. The MIC was observed at the $400 \mathrm{mg} / \mathrm{L}$, which implies the similar metabolic response to heavy metal impact by two different species.

GRUJIĆ et al. (2017a) have tested the influence of heavy metals $\left(\mathrm{Hg}^{2+}, \mathrm{Cu}^{2+}\right.$, and $\left.\mathrm{Pb}^{2+}\right)$ on the Rhodotorula mucilaginosa and Saccharomyces boulardii biofilm and planktonic cells. The $R$. mucilaginosa planktonic cells showed the tolerance in the presence of all tested metals, while while the $S$. boulardii planktonic cells only tolerated $\mathrm{Pb}^{2+}(\mathrm{MICp} 0.43 \mathrm{mM})$.

\section{Tolerance of biofilms to heavy metals}

The heavy metal tolerance of $R$. mucilaginosa and $S$. boulardii biofilms was analyzed. $R$. mucilaginosa formed the biofilm after $48 \mathrm{~h}$ of exposure, while $S$. boulardii did not exhibit the biofilm formation ability. The results of $R$. mucilaginosa heavy metal tolerance is presented in the Table 2 . 
Table 2. Heavy metal tolerance of the $R$. mucilaginosa biofilm at exposure period of $48 \mathrm{~h}$.

\begin{tabular}{lc}
\hline Test substance & ${ }^{1}$ MBEC \\
\hline $\mathbf{C d} \mathbf{2}^{++}$ & $>100$ \\
$\mathbf{Z n}^{2+}$ & $>100$ \\
$\mathbf{N i}^{2+}$ & $>20.67$ \\
Amphotericin B & $>15.15$ \\
\hline
\end{tabular}

${ }^{1} \mathrm{MBEC}$ - minimum biofilm eradication concentration; given as $\mathrm{mM}$ for metals and $\mu \mathrm{g} / \mathrm{mL}$ for antimycotic.

The obtained results showed a significant difference in metal tolerance between the $R$. mucilaginosa biofilm and planktonic cells. The $R$. mucilaginosa biofilm was more tolerant in the presence of all tested metals, compared to planktonic cells. This is due to the extracellular polymeric substances (EPS) that surround the cells in biofilms. Furthermore, it is confirmed, and our results were similar to the results of HARRISON et al. (2006), who examined the effect of heavy metal $\left(\mathrm{AsO}_{4}{ }^{3-}, \mathrm{Cd}^{2+}, \mathrm{Pb}^{2+}, \mathrm{Ni}^{2+}, \mathrm{SeO}_{3}{ }^{2-}, \mathrm{CrO}_{4}{ }^{2-}, \mathrm{Mn}^{2+}, \mathrm{Co}^{2+}, \mathrm{Cu}^{2+}, \mathrm{Ag}^{+}, \mathrm{Zn}^{2+}, \mathrm{Hg}^{2+}\right.$, $\mathrm{Al}^{3+}, \mathrm{AsO}_{2}{ }^{-}, \mathrm{SeO}_{3}{ }^{2-}, \mathrm{Te}_{3}{ }^{2-}$ ) on Candida tropicalis biofilm.

\section{Fluorescence microscopy}

The fluorescence microscopy was used as visual confirmation of already obtained results through MBEC. The impact of heavy metals and amphotericin $\mathrm{B}$ on the $R$. mucilaginosa biofilm were observed and results were shown in Figure 1-4.

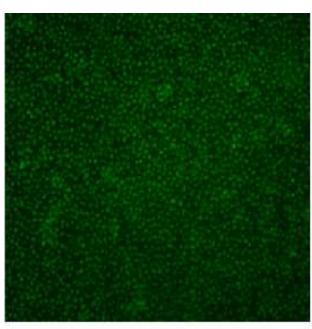

growth control

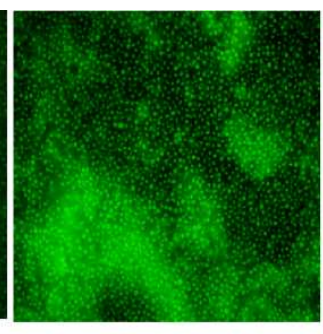

$0.1 \mathrm{mM}$

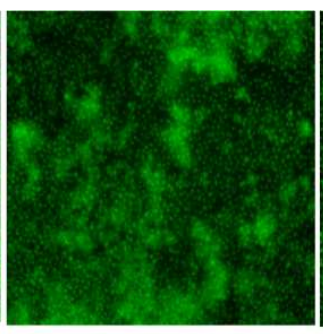

$1 \mathrm{mM}$

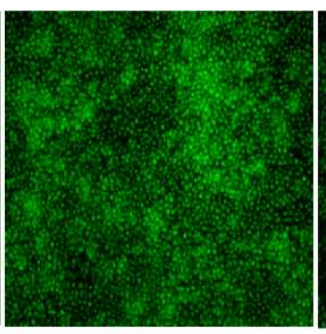

$10 \mathrm{mM}$

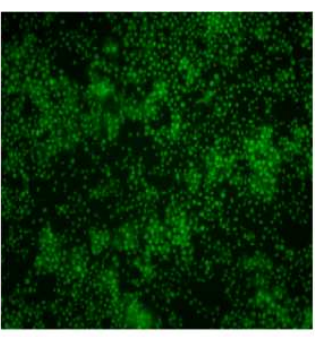

$100 \mathrm{mM}$

Figure 1. The effect of $\mathrm{Cd}^{2+}$ on the R. mucilaginosa biofilm.

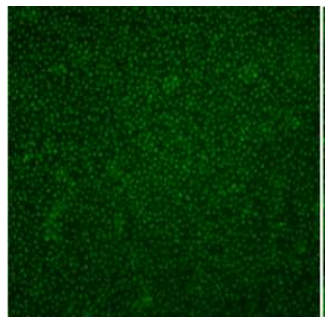

growth control

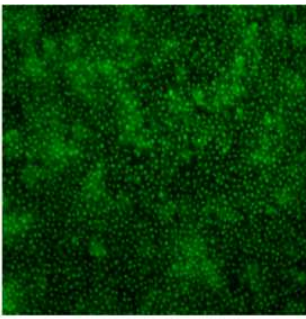

$0.1 \mathrm{mM}$

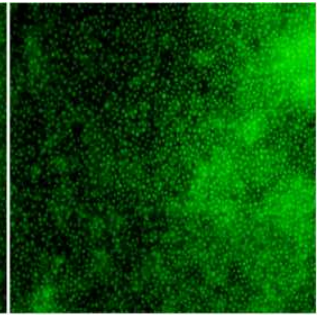

$1 \mathrm{mM}$

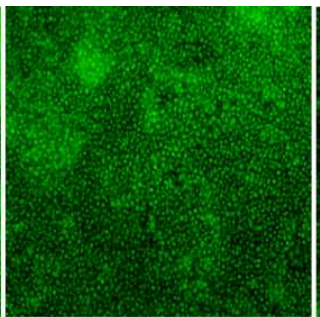

$10 \mathrm{mM}$

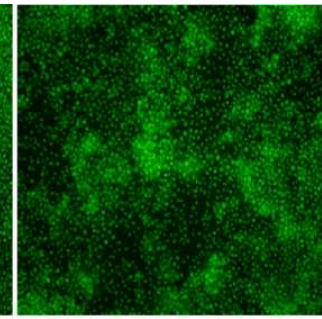

$100 \mathrm{mM}$

Figure 2. The effect of $\mathrm{Zn}^{2+}$ on the R. mucilaginosa biofilm 


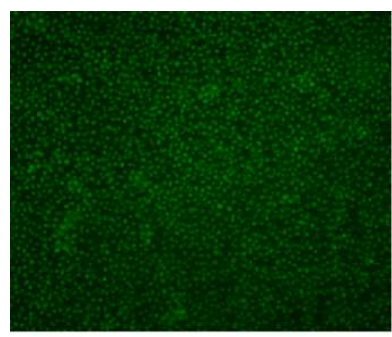

growth control

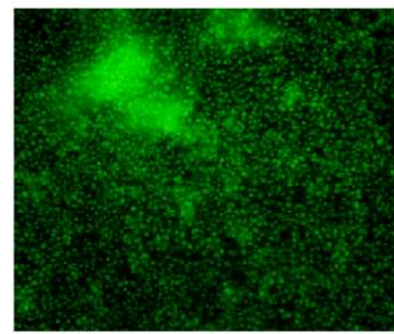

$5.17 \mathrm{mM}$

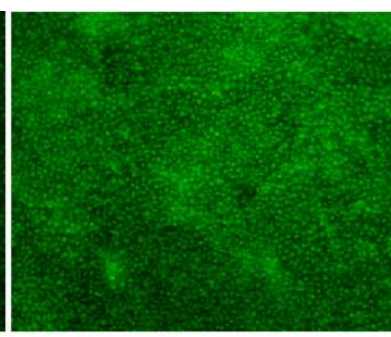

$0.64 \mathrm{mM}$

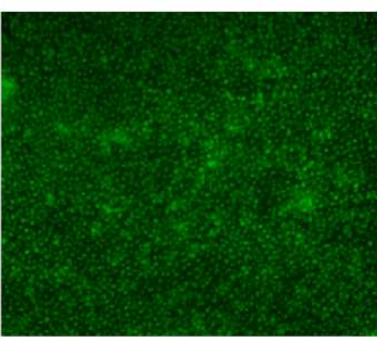

$10.33 \mathrm{mM}$

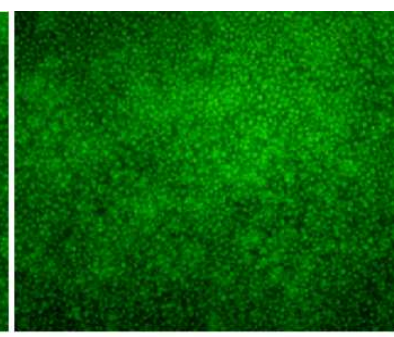

$1.30 \mathrm{mM}$

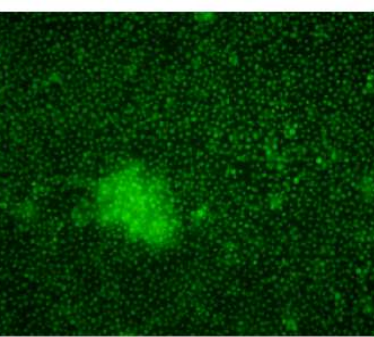

$15.5 \mathrm{mM}$

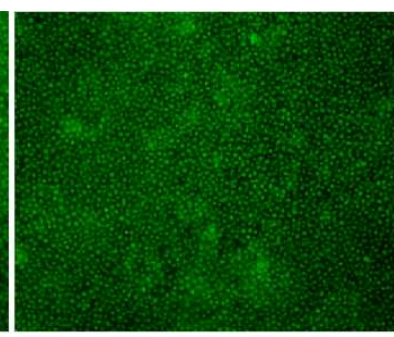

$2.58 \mathrm{mM}$

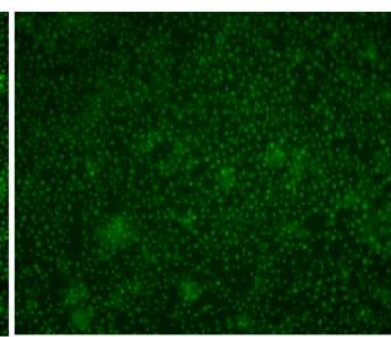

$20.67 \mathrm{mM}$

Figure 3. The effect of $\mathrm{Ni}^{2+}$ on the R. mucilaginosa biofilm

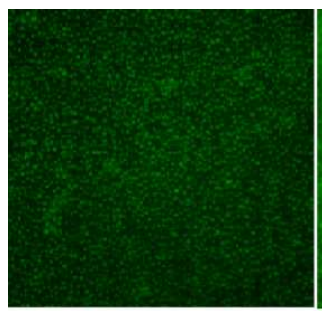

growth control

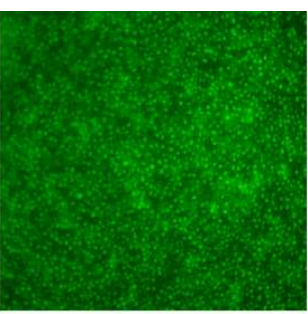

$1.89 \mu \mathrm{g} / \mathrm{ml}$

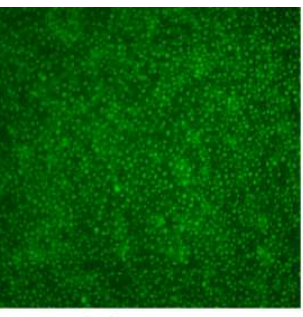

$3.78 \mu \mathrm{g} / \mathrm{ml}$

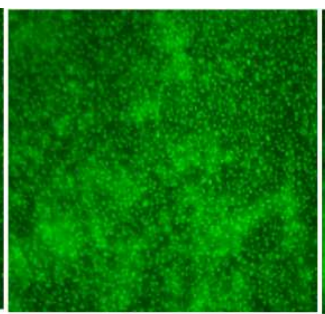

$7.57 \mu \mathrm{g} / \mathrm{ml}$

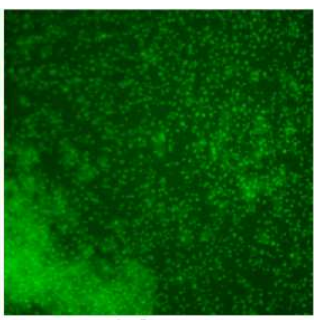

$15.15 \mu \mathrm{g} / \mathrm{ml}$

Figure 4. The effect of amphotericin $\mathrm{B}$ on the $R$. mucilaginosa biofilm

The results of reading the optical density at microplate rider were in accordance with the results of fluorescence microscopy.

\section{Metal removal efficiency using planktonic cells and biofilm}

The percentage of heavy metals removal by $R$. mucilaginosa planktonic cells after 48 hours of incubation is shown in the Table 3. The removal percentage of $\mathrm{Cd}^{2+}, \mathrm{Zn}^{2+}$ and $\mathrm{Ni}^{2+}$ were $2.11 ; 4.99 ; 29.25 \%$, respectively.

Table 3. Metal removal efficiency using $R$. mucilaginosa planktonic cells (\%).

\begin{tabular}{llll}
\hline Time & $\mathbf{C d}^{\mathbf{2 +}}$ & $\mathbf{Z n}^{\mathbf{2 +}}$ & $\mathbf{N i}^{\mathbf{2 +}}$ \\
\hline $\mathbf{1 2} \mathbf{~ h}$ & 1.11 & 2.57 & 2.42 \\
$\mathbf{2 4} \mathbf{~ h}$ & 1.49 & 3.15 & 3.03 \\
$\mathbf{4 8} \mathbf{~ h}$ & 2.11 & 4.99 & 29.25 \\
\hline
\end{tabular}

The efficiency in $\mathrm{Ni}^{2+}$ removal by Candida spp. (planktonic cells) isolated from sewage was determined by DÖNMEZ and ZÜMRIYE (2001), at initial concentration of 100 $\mu \mathrm{g} / \mathrm{mL}$. Percentage of $\mathrm{Ni}^{2+}$ removal, after 5-15 days was 29-57\%. In our study, $R$. mucilaginosa removed $29.25 \% \mathrm{Ni}^{2+}$ after $48 \mathrm{~h}$, at initial concentration of $100 \mu \mathrm{g} / \mathrm{mL}$. The 
results obtained for $\mathrm{Ni}^{2+}$ in the mentioned study are similar with the results obtained in this study.

Removal of $\mathrm{Cd}^{2+}, \mathrm{Zn}^{2+}$ and $\mathrm{Ni}^{2+}$ ions using the $R$. mucilaginosa biofilm was tested. The results are presented in the Table 4.

Table 4. Metal removal by $R$. mucilaginosa biofilm (\%).

\begin{tabular}{cccc}
\hline Time & $\mathbf{C d}^{2+}$ & $\mathbf{Z n}^{\mathbf{2 +}}$ & $\mathbf{N i}^{2+}$ \\
\hline $\mathbf{1 2} \mathbf{h}$ & 81.12 & 82.22 & 77.85 \\
$\mathbf{2 4} \mathbf{h}$ & 83.49 & 85.04 & 87.23 \\
$\mathbf{4 8} \mathbf{~ h}$ & 90.71 & 89.62 & 91.24 \\
\hline
\end{tabular}

The metal removal efficiency of the $R$. mucilaginosa biofilm was better, compared to the planktonic cells. Obtained results showed that the $R$. mucilaginosa biofilm removed over $90 \%$ of every tested metal after $48 \mathrm{~h}$. These results are in accordance with the results of BASAK et al. (2014), who reported $88 \%$ and $72.2 \% \mathrm{Zn}^{2+}$ removal by Candida rugosa and Cryptococcus laurentii biofilm, respectively, for $24 \mathrm{~h}$. The percentage of $\mathrm{Zn}^{2+}$ removal in our study after 24 hours was $85.04 \%$, which was in accordance with results of mentioned studies.

\section{CONCLUSION}

Our findings suggest that biofilm and planktonic populations show different levels of tolerance to heavy metals. Understanding this difference is significant for understanding the microbial ecology of environments polluted with heavy metals, as well as the basics of biofilm tolerance to antimicrobial agents in general. This study gives an insight about the ability of $R$. mucilaginosa to form biofilm on coverslips and remove metal ions $\left(\mathrm{Cd}^{2+}, \mathrm{Zn}^{2+}\right.$, $\mathrm{Ni}^{2+}$ ) as an inexpensive and alternative method to traditional techniques for removal of heavy metals from waste waters. Our results indicate that biofilm has a higher ability to remove heavy metals compared to planktonic cells, which suggests that biofilm has a better potential for application in the environment remediation. The ability of the $R$. mucilaginosa biofilm to remove $\mathrm{Cd}^{2+}, \mathrm{Zn}^{2+}$ and $\mathrm{Ni}^{2+}$ ions could be used in some future examinations on real effluent.

\section{Acknowledgments}

This study was supported by a project (No. III41010) of Ministry of Education, Science and Technological Development of the Republic of Serbia.

\section{References:}

[1] Ahalya, N., Ramachandra, T.V., Kanamadi, R.D. (2003): Biosorption of heavy metals. Research Journal of Chemistry and Environment, 7 (4): 71-79.

[2] Al-EnZI, R.M., Al-CharRakH, A.H. (2013): Heavy Metals Resistance of Pseudomonas aeruginosa Isolated from Clinical and Environmental Sources in Hilla City. Medical Journal of Babylon 10 (1): 110-119. 
[3] Alloway, B.J. (1995): Introduction. In: Alloway, B.J. (ed). Heavy Metals in Soils, Springer, Netherlands 2: 3-9.

[4] Alluri, H.K., Ronda, S.R., Settalluri, V.S., Bondili, J.S., Suryanarayana, V., VENKATESHWAR, P. (2007): Biosorption: An eco-friendly alternative for heavy metal removal. African Journal of Biotechnology 6 (25): 2924-2931. doi: 10.5897/AJB2007.000-2461

[5] Basak G., Lakshmi V., Chandran P., Das N. (2014): Removal of Zn (II) from electroplating effluent using yeast biofilm formed on gravels: batch and column studies. Journal of Environmental Health Science and Engineering 12 (1): 1-11. doi: $10.1186 / 2052-336 \mathrm{X}-12-8$

[6] Buzejić, A., Grujić, S., RAdojević, I., Ostojić, A., Čomić, LJ., Vasić, S. (2016): Pb and Hg Heavy Metal Tolerance of Single- and Mixed species Biofilm (Rhodotorula mucilaginosa and Escherichia coli). Kragujevac Journal of Science 38: 115-124. doi: 10.5937/KgJSci1638115B

[7] Ceri, H., Olson, M.E., Stremick, C., Read, R.R., Morck, D., Buret, A. (1999): The Calgary Biofilm Device: new technology for rapid determination of antibiotic susceptibilities of bacterial biofilms. Journal of Clinical Microbiology 37 (6): 17711776.

[8] DönMEZ, G., ZÜMrIYE, A. (2001): Bioaccumulation of copper (II) and nickel (II) by the non-adapted and adapted growing Candida sp. Water Research 35 (6): 1425-1434 doi: 10.1016/S0043-1354(00)00394-8

[9] Fazli, M.M., Soleimani, N., Mehrasbi, M., Darabian, S., Mohammadi, J., RAMAZANI, A. (2015): Highly cadmium tolerant fungi: their tolerance and removal potential. Journal of Environmental Health Science and Engineering 13 (19): 1-9. doi: 10.1186/s40201-015-0176-0

[10] Grujić, S., VAsić, S., RAdojević, I., ČOMIĆ, LJ., Ostojić, A. (2017a): Comparison of the Rhodotorula mucilaginosa Biofilm and Planktonic Culture on Heavy Metal Susceptibility and Removal Potential. Water Air Soil Pollution 228: 73. doi: 10.1007/s11270-017-3259-y

[11] Grujić, S., VAsić, S., Čomić, LJ., Ostojić, A., RAdOJEviĆ, I. (2017b): Heavy metal tolerance and removal potential in mixed-species biofilm. Water Science and Technology 76 (4): 806-812. doi: 10.2166/wst.2017.248

[12] Harrison, J.J., Rabiei, M., Turner, R.J., Badry, E.A., Sproule, K.M., Ceri, H. (2006): Metal resistance in Candida biofilms. FEMS Microbiology Ecology 55 (3): 479491. doi: 10.1111/j.1574-6941.2005.00045.x

[13] Kronvall, G., MYhre, E.B. (1977): Differential staining of bacteria in clinical specimens using acridine orange buffered at low pH. Acta Pathologica et Microbiologica Scandinavica - Section B, Microbiology 85 (4): 249-250. doi: 10.1111/j.1699-0463.1977.tb01970.x

[14] LI, Z., YUAN, H. (2006): Characterization of cadmium removal by Rhodotorula sp. Y11. Applied Microbiology and Biotechnology 73 (2): 458-463. doi: 10.1007/s00253-0060473-8

[15] LI, Z., YUAN, H. (2008): Responses of Rhodotorula sp. Y11 to cadmium. Biometals 21 (6): 613-621. doi: 10.1007/s10534-008-9147-6 
[16] Muneer, B., Shakoori, F.R., Rehman, A., ShaKoori, A.R. (2007): Chromium resistant yeast with multimetal resistance isolated from industrial effluents and their possible use in microbial consortium for bioremediation of wastewater. Pakistan Journal of Zoology 39 (5): 289-297.

[17] Rezza, I., Salinas, E., Elorza, M., DE Tosetti, M.S., Donati, E. (2001): Mechanisms involved in bioleaching of an aluminosilicate by heterotrophic microorganisms. Process Biochemistry 36 (6): 495-500. doi: 10.1016/S0032-9592(00)00164-3

[18] Salinas, E., de Orellano, M.E., Rezza, I., Martinez, L., Marchesvky, E., De TOSETTI M.S. (2000): Removal of cadmium and lead from dilute aqueous solutions by Rhodotorula rubra. Bioresource Technology 72 (2): 107-112. doi: 10.1016/S09608524(99)00111-X

[19] SAN, N.O., DÖNMEZ, G. (2012): Biosorption of chromium (VI), nickel (II) and Remazol Blue by Rhodotorula muciloginosa biomass. Water Science and Technology 65 (3): 471-477. doi: 10.2166/wst.2012.872

[20] Suazo-Madrid, A., Morales-Barrera, L., Aranda-García, E., Cristiani-Urbina, E. (2011): Nickel (II) biosorption by Rhodotorula glutinis. Journal of Industrial Microbiology and Biotechnology 38 (1): 51-64. doi: 10.1007/s10295-010-0828-0 